UDK 7.041.5:929 Marija Terezija

929 Marija Terezija, austr. carica

Primljeno: 7. 6. 2018.

Prihvaćeno: 24. 10. 2018.

Pregledni rad

DOI: $10.22586 /$ pp.v55i0.84

\title{
Portraits of the Queen and Empress Maria Theresia in North-Western Croatia An Overview
}

The paper presents a chronological overview of portraits of Empress Maria Theresia in museum collections of north-western Croatia - Zagreb, Varaždin and Trakošćan. The early portraits of Maria Theresia as the heiress to the throne are smaller in size, portraying her as the Austrian archduchess, while portraits after her ascension to the throne are mostly large, stressing the official use they were intended for. They range in quality from those painted by well-known Viennese court artists up to representations by highly or less skilled anonymous artists. Martin van Meytens the Younger stands out as the most prominent portraitist of the Empress; together with his workshop he provided the whole Austrian Empire with numerous portraits of Maria Theresia and her husband. Most of her portraits painted between 1741 and 1760, held in museum collections in north-western Croatia, are attributed to Meytens and / or his workshop.

Portraits of Empress Maria Theresia in museum collections of north-western Croatia present the monarch in different stages of her life - as a young archduchess and heiress to the throne, a mighty ruler and mother, and finally a grieving widow. They remain a constant reminder of the greatness she had achieved as the only female monarch of the vast multinational Habsburg Empire.

Keywords: Maria Theresia, portraits, museum collections, north-western Croatia, Martin van Meytens the Younger

From the end of the $18^{\text {th }}$ and especially during the $19^{\text {th }}$ century portraits of rulers were compulsory in various official institutions such as government offices, county seats, assembly halls, town halls, military commands and schools. Por-

\footnotetext{
Marina Bregovac Pisk, Croatian History Museum, Matoševa 9, 10000 Zagreb, Croatia, E-mail: m.pisk@hismus.hr
} 
traits of $18^{\text {th }}$ century rulers in Croatia are not as easily found as the $19^{\text {th }}$ century ones; nevertheless, the present-day museum collections in north-western Croatia hold a number of portraits of Empress Maria Theresia and members of her family, ranging from those painted by well-known Viennese court artists up to representations by highly or less skilled anonymous artists.

The early portraits of Maria Theresia as the heiress to the throne are smaller in size portraying her as Austrian archduchess, while portraits after her ascension to the throne are mostly large, stressing the official use they were intended for.

\section{Early portraits}

Picture 1. Unknown painter (Frans von Stampart?), Archduchess Maria Theresia

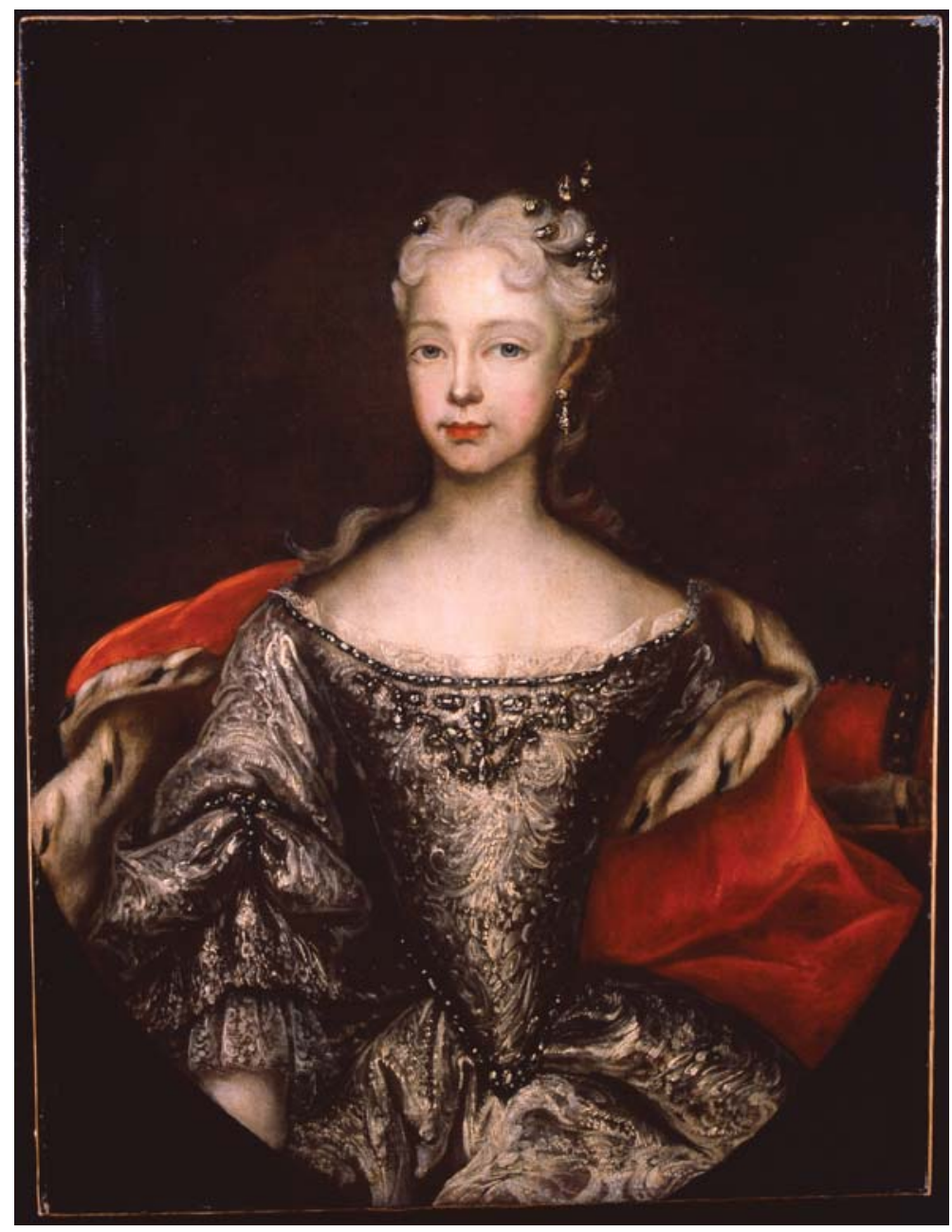

Source: Croatian History Museum, Zagreb (HPM/PMH 2428) 
A chronological display of portraits of the empress shows that the earliest portraits in this part of Croatia date from the time of her engagement to Francis Stephen of Lorraine in 1736 (Francis I, Holy Roman Emperor). The young couple is shown on a pair of portraits in the Croatian History Museum; ${ }^{1}$ they were tentatively attributed to Frans von Stampart (Antwerp, 1675 - Vienna, 1750), who was in Vienna from 1698, working as a court painter. The possible attribution to von Stampart was made by Marijana Schneider in the 1982 catalogue, based on the similarities between the painting in the Croatian History Museum and a print in the Bildarchiv of the Austrian National Library, done by Franz Leopold Schmittner after a painting by Franz von Stampart, done after $1740 .^{2}$ The print does show some similarities with the portrait, the basic difference being in the treatment of the head of the young archduchess. It is also possible that the portrait was done after the print, albeit by a very skilled artist.

As the two portraits were painted before Maria Theresia's ascension to the throne, they obviously did not have the "official" function of representing the ruler, instead marking the young girl as a member of the Austrian ruling family, with the Erzherzogshut (the archduke's hat) in the background to the right. ${ }^{3}$ We do not know how the Museum acquired the portraits but it can be safely assumed that they must have come from one of the high-ranking noble families in Croatia, perhaps the Drašković family, who had a similar gallery of oval portraits representing rulers and Croatian viceroys as well as the members of the Drašković family.

The next pair of portraits of Maria Theresia and her husband Francis Stephen is kept in the collection of the Croatian History Museum as well. They were probably painted between 1736 and 1741 by an unknown, possibly Viennese, artist. ${ }^{4}$ The portrait of Maria Theresia has not undergone restoration, so it is at the moment not possible to say more about its author.

This pair of portraits resembles the small double portrait of Maria Theresia and her husband Francis Stephen in the Kunsthistorisches Museum in Vienna, ${ }^{5}$

\footnotetext{
1 Portrait of Maria Theresia, oil on canvas, 87 x $66 \mathrm{~cm}$, unsigned, Croatian History Museum, inv. no. HPM/PMH 2428; portrait of Francis Stephen, oil on canvas, 79 x $62 \mathrm{~cm}$, unsigned, Croatian History Museum, inv. no. HPM/PMH 2445. The two portraits were first published in Marijana Schneider, Portreti 16-18. stoljeća (Zagreb: Povijesni muzej Hrvatske, 1982), 113-114, 137.

2 Print by Schmittner after von Stampart at Austrian National Library (Österreichische Nationalbibliothek), http://data.onb.ac.at/rec/baa4831566 (last accessed on December 1, 2017).

3 At the time of her engagement due to the Pragmatic sanction of 1712, Maria Theresia was known to be the heiress to the throne.

4 Portrait of Maria Theresia, oil on canvas, 97 x $69.5 \mathrm{~cm}$, unsigned, Croatian History Museum, inv. no. HPM/PMH 10263; portrait of Francis Stephen, oil on canvas, 97 x $69.5 \mathrm{~cm}$, unsigned, Croatian History Museum, inv. no. HPM/PMH 2793. First published in Schneider, Portreti 16 - 18. stoljeća, 115, 138-139.

5 Double portrait $(18.1 \times 26 \mathrm{~cm})$, Vienna, Kunsthistorisches Museum, Gemäldegalerie; lately published in Maria Theresia 1717 - 1780, Strategin - Mutter - Reformerin, exhibition catalogue, ed. Elfriede Iby, Martin Mutschlechner, Werner Telesko and Karl Vocelka (Vienna: Schloss Schönbrunn, Amalthea and Kunsthistorisches Museum, 2017), 85, 216.
} 
painted by an unknown artist at the time of their engagement in 1736. The portrait of Maria Theresia also shows some similarities with the engraving by Jan Lauwryn Krafft ${ }^{6}$ dated in 1742, done after a portrait by Andreas Möller ${ }^{7}$ from 1741. The portraits were privately owned, collected after the Second World War by the Komisija za sakupljanje i čuvanje kulturnih spomenika i starina [Commission for Collecting and Preserving Cultural Monuments and Antiquities $]^{8}$ and handed over to the Museum in 1952. They have all the elements of semi-official portraits, with the archducal crowns in the background.

The next portrait of Maria Theresia in a museum collection in this part of Croatia is probably the one in the Varaždin City Museum, ${ }^{9}$ presented to the public in 2015 in a two-part exhibition entitled Varaždin pod krunom Habsburgovaca [Varaždin under the Habsburg Crown]. The exhibition was accompanied by a catalogue ${ }^{10}$ in which, among other valuable texts, Mirjana Dučakijević wrote about the Habsburg portraits in the holdings of the Varaždin City Museum. ${ }^{11}$ She states that the portrait of Maria Theresia was painted after her father's death in 1740, as she is represented with a small black veil; therefore the portrait could have been done by an unknown, probably Viennese, artist probably in $1741 .{ }^{12}$ The portrait could have been painted in 1744/45, since the black veil might actually be connected as tothe death of her beloved sister, Maria Anna, ${ }^{13}$ but in that case we would expect the Hungarian crown in the background, instead of the Austrian archducal hat. The portrait was obviously not intended for official use, but more likely for private ownership of a noble family. Since Varaždin was the seat of the Croatian parliament and government until the great fire of 1776 , Croatian noble families had their palaces and town houses there, decorated with various portraits of family members and rulers. ${ }^{14}$

6 Engraver, etcher and wood engraver Jan Lauwryn Krafft (Bruxelles, 1694-1765) is the author of numerous prints, amongst them the illustrations for the Histoire générale de l'auguste maison d'Autriche (Bruxelles, 1744-1745) containing portraits of Austrian rulers from Rudolf von Habsburg to Maria Theresia.

7 Portraitist Andreas Möller (Kopenhagen, 1684 - Berlin, 1762?) worked in London and Germany, in 1724 and 1737 in Vienna. The print by Krafft after Möller is to be found at the Austrian National Library (Österreichische Nationalbibliothek), http://data.onb.ac.at/rec/baa4831344 (last accessed on November 28, 2017).

8 Usually referred to as the KOMZA.

9 Portrait of Maria Theresia, oil on canvas, 88 x $69 \mathrm{~cm}$, unsigned, Varaždin City Museum, inv. no. GMV GS 424. First published in Miran Bojanić Morandini et al., Varaždin pod krunom Habsburgov$a c a$, exhibition catalogue (Varaždin: Gradski muzej Varaždin, 2015), 140.

10 See footnote no 9.

11 Mirjana Dučakijević, “Vladarski portreti Habsburgovaca u Gradskom muzeju Varaždin”, in: Miran Bojanić Morandini et al., Varaždin pod krunom Habsburgovaca, exhibition catalogue (Varaždin: Gradski muzej Varaždin, 2015), 51-55.

12 Bojanić Morandini et al., Varaždin pod krunom Habsburgovaca, 140.

${ }_{13}$ Maria Anna, Maria Theresia's sister, was married to Karl Alexander von Lothringen, brother of Francis Stephen, in 1744. By the end of that year she died in childbirth.

14 Dučakijević, "Vladarski portreti Habsburgovaca", 52. 


\section{Portraits painted after 1740}

The empress depicted on a horse as the Hungarian ruler, a small-scale variation of numerous representations of that interesting subject, is kept at the Croatian History Museum. ${ }^{15}$

Picture 2. Unknown painter, King Maria Theresia

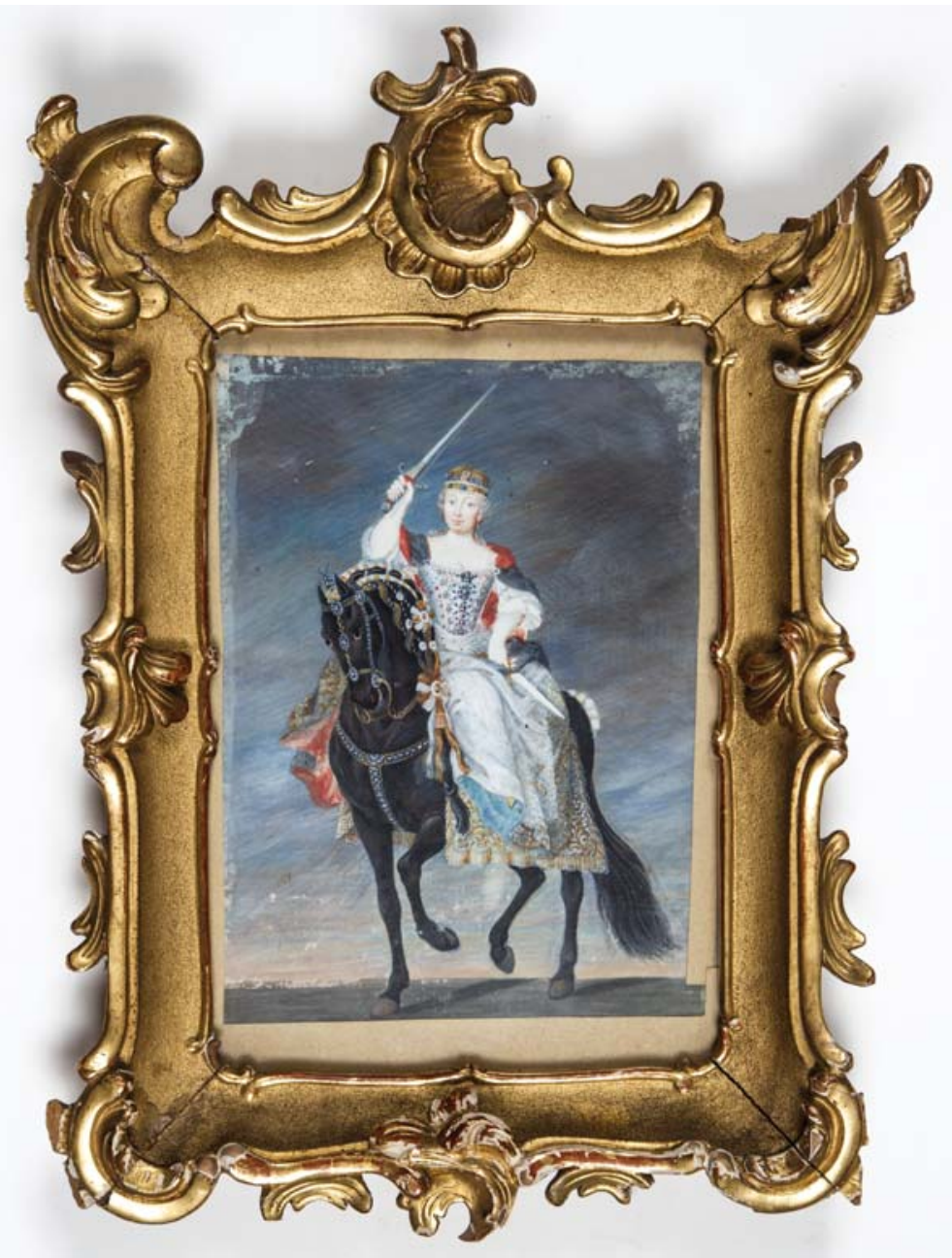

Source: Croatian History Museum, Zagreb (HPM/PMH 24683)

\footnotetext{
15 Maria Theresia on a horse, gouache on paper, 183 x $135 \mathrm{~mm}$, unsigned, Croatian History Museum, inv. no. HPM/PMH 24683. First published in Gerda Mraz, Gerald Schlag, ed., Maria Theresia als Königin von Ungarn, exhibition catalogue (Schloss Halbturn, 1980), 162, afterwards in Schneider, Portreti 16-18. stoljeća, 114-115.
} 
The most well-known of those paintings is the one by Martin van Meytens the Younger (who painted the portrait) and Philipp Ferdinand Hamilton (who painted the horse) at the Hungarian National Gallery in Budapest. ${ }^{16}$ The motif is related to the official crowning ceremony of Hungarian kings, showing Maria Theresia on the coronation hill in Bratislava (Pressburg). The gouache in the Croatian History Museum shows her riding a black horse, wearing a special dress made for the Hungarian coronation, wearing the Hungarian insignia (the crown of St Stephen, the sword and the coronation mantle). Judging by the posture of the empress' left hand, the author of the gouache had apart from various representations showing the queen on a horse during the crowning ceremony probably also seen a coloured engraving by Martin Engelbrecht and Christian Wilhelm, dated between 1741 and $1760 .{ }^{17}$ The small picture in the Croatian History Museum was privately owned, collected after the Second World War by the Komisija za sakupljanje i čuvanje kulturnih spomenika i starina [Commission for Collecting and Preserving Cultural Monuments and Antiquities], and given to the Museum in 1952.

The portrait by an unknown author in the Trakošćan Castle Museum, the former seat of the Drašković family, was probably painted sometime between 1741 and 1745; Maria Theresia is represented as the queen of Hungary, showing the Hungarian crown in the background to the left. ${ }^{18}$ The author might have been a painter close to Jean-Étienne Liotard (1702-1789), a portraitist who had done portraits of Maria Theresia and her husband in the early 1740 's. It also holds some reminiscences of portraits of the young archduchess by the court painter Martin van Meytens, done in the mid- and late thirties of the $18^{\text {th }}$ century. ${ }^{19}$

${ }_{16}$ Georg Lechner, Martin van Meytens der Jüngere, exhibition catalogue (Vienna: Belvedere, 2014), ed. Agnes Husslein-Arco and Georg Lechner, 46-49. Also Szabolcs Serfözö, “'Männlich’ und mächtig, Die Inszenierung Maria Theresias als Königin von Ungarn auf Staatsporträts”, in: Maria Theresia 1717 - 1780, Strategin - Mutter - Reformerin, exhibition catalogue, ed. Elfriede Iby, Martin Mutschlechner, Werner Telesko and Karl Vocelka (Vienna: Schloss Schönbrunn, Amalthea and Kunsthistorisches Museum, 2017), 107-111.

17 Published in Zuzana Hanzelová, Retrospect to Bratislava Coronations (From the collection of the Bratislava Gallery) (Bratislava: Galérie mesta Bratislavy, 1992), 54. Drawing by Christian Wilhelm, engraving by Martin Engelbrecht (Web umenia, https://www.webumenia.sk/dielo/SVK:GMB.C_7635 (last accessed on November 28, 2017).

18 Portrait of Maria Theresia, oil on canvas, 93 x $77 \mathrm{~cm}$, unsigned, Trakošćan Castle Museum, inv. no. DT 1217. Catalogued in Marina Bregovac Pisk, "Obitelj Drašković kao naručitelji i kupci umjetnina (na primjeru Dvora Trakošćan)” [The Drašković Family as Commissioners and Buyers of Works of Art (A Case Study of the Trakošćan Castle)], (doctoral thesis, University of Zagreb, Faculty of Humanities and Social Sciences, 2012), 114-115.

19 Lechner, Martin van Meytens der Jüngere, 42-45. 
Portraits of Maria Theresia and Francis Stephen given to the Croatian History Museum by the Zagreb City administration in 1919 were probably painted in $1743 .{ }^{20}$ The painter was not especially skilled and the only interesting element in the portrait of Maria Theresia is the jewellery shaped like lilies of the valley. The crowns and sceptre are depicted to her left (the Austrian Archduke's Hat and the Hungarian Crown). Francis Stephen is not shown with the crown of the Holy Roman Empire, which was his from 1745 onwards. Therefore we can safely assume that the portraits were painted before that date, possibly by a local Croatian artist.

\section{Portraits by or attributed to Martin van Meytens the Younger}

Martin van Meytens the Younger (Stockholm, 1695 - Vienna, 1770) was the son of the painter Martin van Meytens the Elder who gave him his first lessons. With family ties to the Netherlands, Meytens the Younger studied and worked from 1714 there as well as in Paris and England. From 1721 to 1723 he was in Vienna, followed by a seven-year residence in Italy. From 1731 he lived permanently in Vienna. The next year Meytens had become the court painter of Emperor Charles VI and later on a favourite painter of Maria Theresia and her family, ${ }^{21}$ as well as a valued portraitist of numerous noble Austrian and Hungarian families. ${ }^{22}$ Together with his workshop he provided the whole Austrian Empire with numerous portraits of Maria Theresia and her husband. Most of her portraits painted between 1741 and 1760, held in Northern Croatian museum collections, are attributed to Meytens and / or his workshop.

\footnotetext{
20 Unknown painter, Portrait of Maria Theresia, oil on canvas, 139 x $109 \mathrm{~cm}$, unsigned, Croatian History Museum, inv. no. HPM/PMH 8773; unknown painter, portrait of Francis Stephen, oil on canvas, 138.5 x $108.5 \mathrm{~cm}$, unsigned, Croatian History Museum, inv. no. HPM/PMH 8772. The portraits were published for the first time in Schneider, Portreti 16-18. stoljeća, 115-116, 138.

${ }_{21}$ Upon her ascension to the throne, Maria Theresia strove to consolidate state finances with rigid savings measures. The court artists who were until that time employed and received salaries were dismissed; from then onwards they worked as the Hofbereite, and were paid for their finished works. Maria Theresia also bestowed to those artists whom she particularly valued the honorary title of Kammermaler, which did not include a permanent salary. Sandra Hertel, Stefanie Linsboth, "Maler im Dienste der Kaiserin - Maria Theresia als Reformerin und Mäzenin der Kunstproduktion“, in: Maria Theresia 1717 - 1780, Strategin - Mutter - Reformerin, exhibition catalogue, ed. Elfriede Iby, Martin Mutschlechner, Werner Telesko and Karl Vocelka (Vienna: Schloss Schönbrunn, Amalthea and Kunsthistorisches Museum, 2017), 142.
}

22 From 1759 until his death in 1770 he was the director of the Vienna Academy. 
Picture 3. Martin van Meytens the Younger (?), Queen Maria Theresia

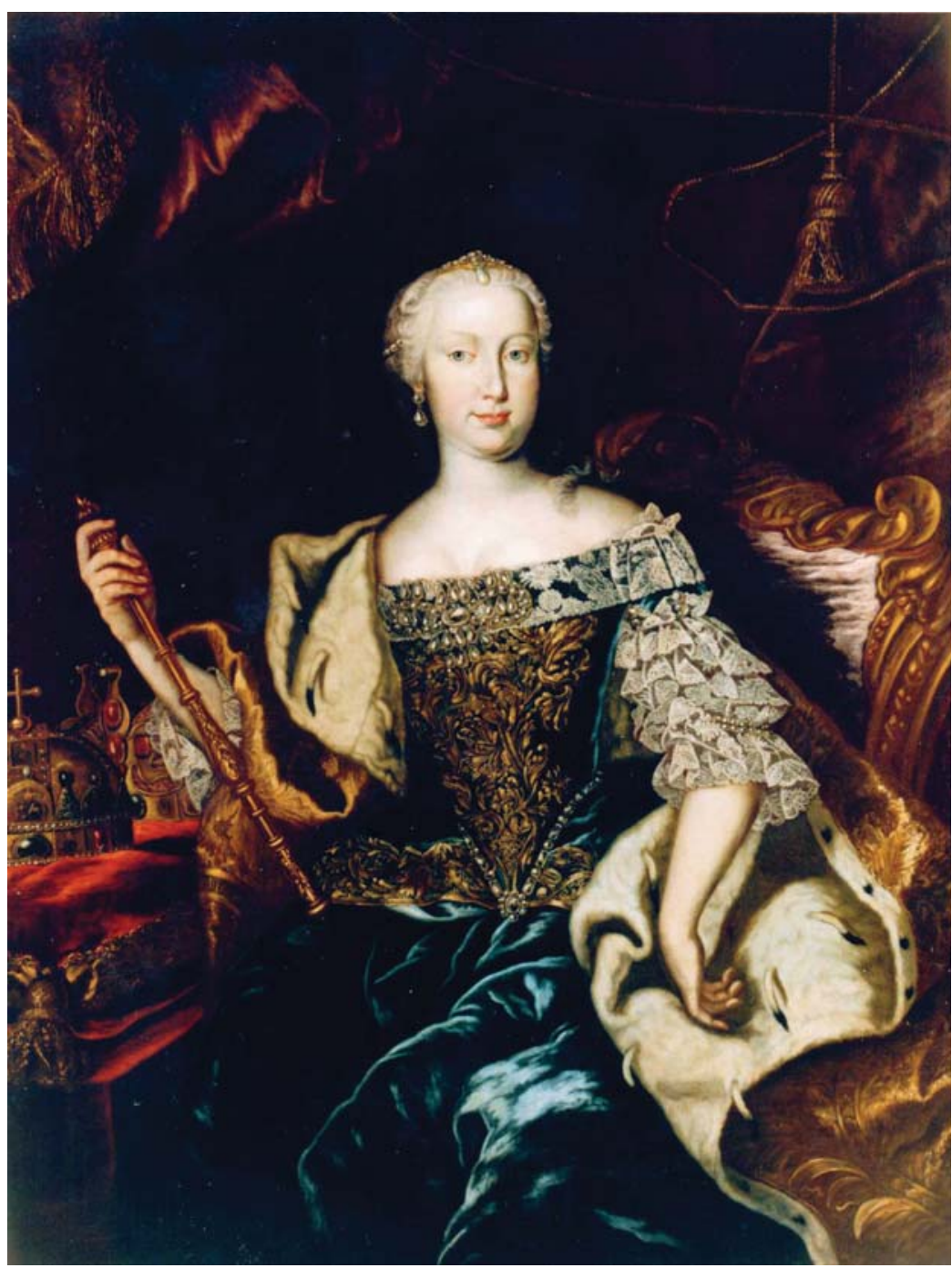

Source: Zagreb City Museum (MGZ 1349)

The Zagreb City Museum has in its permanent display a magnificent portrait of the young monarch, attributed to Martin van Meytens the Younger, painted between 1743 and $1745 .{ }^{23}$ In her right hand she holds a sceptre, and next to it on a red cushion is the Hungarian crown with the Bohemian crown ${ }^{24}$ behind it.

\footnotetext{
${ }^{23}$ Martin van Meytens the Younger (?), portrait of Maria Theresia, oil on canvas, 143 x $110 \mathrm{~cm}$, unsigned, Zagreb City Museum, inv. no. MGZ 1349.

${ }^{24}$ She was crowned in Prague in 1743.
} 
Picture 4. Martin van Meytens the Younger, Empress Maria Theresia

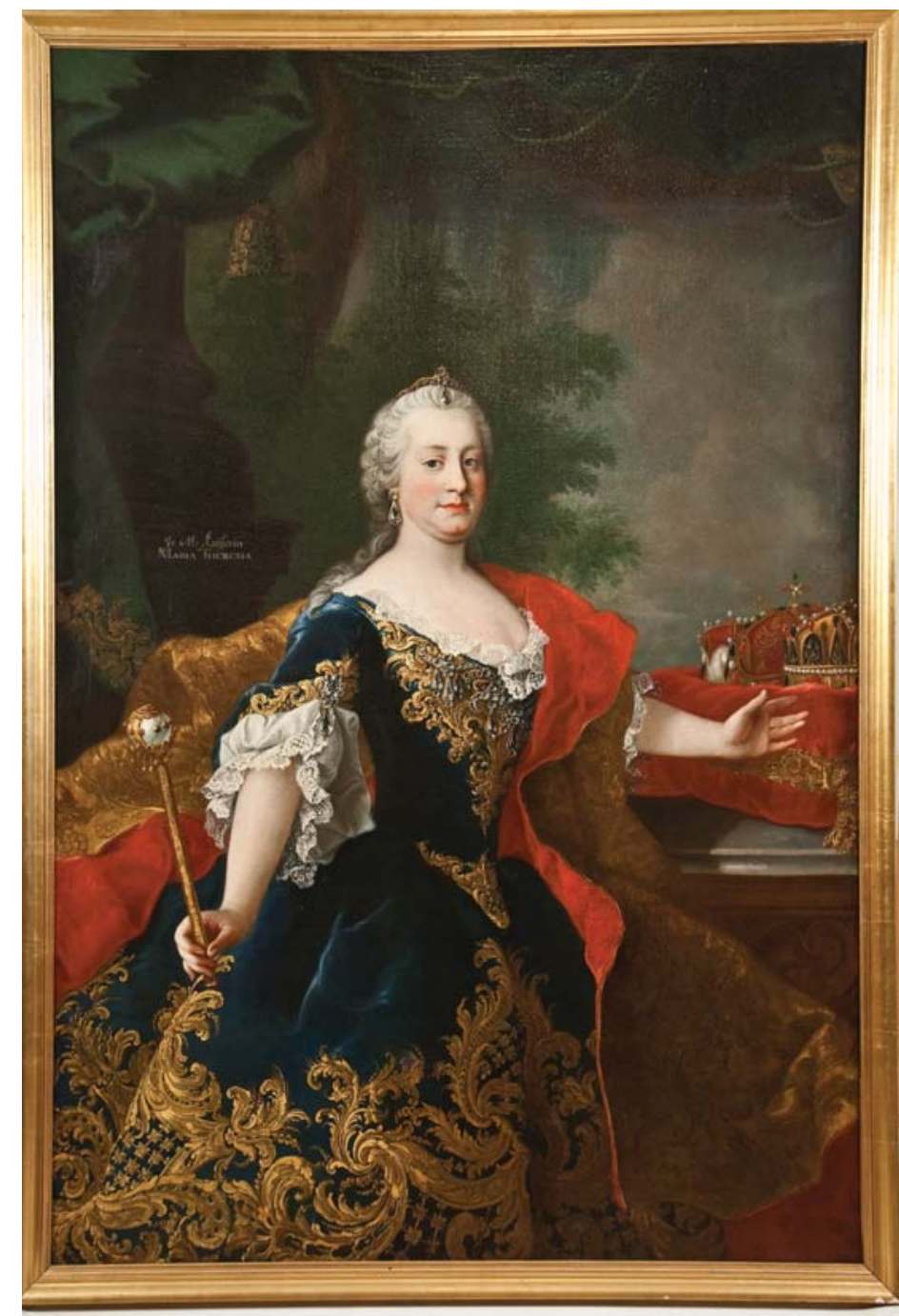

Source: Croatian History Museum, Zagreb (HPM/PMH 2448)

Meytens is the author of the large portrait donated to the Croatian History Museum by the Bjelovar County in 1940. ${ }^{25}$ Painted probably between 1745 and 1750, the portrait shows Maria Theresia in a dark blue gown adorned with golden embroidery, holding the sceptre in her right hand, while pointing with the left to the

\footnotetext{
${ }^{25}$ Martin van Meytens the Younger, Portrait of Maria Theresia, oil on canvas, 172.5 x $115 \mathrm{~cm}$, unsigned, Croatian History Museum, inv. no. HPM/PMH 2448. Published for the first time in Schneider, Portreti 16-18. stoljeća, 116.
} 
red cushion with Austrian Archducal, Bohemian and Hungarian crowns. This is certainly the most representative portrait of the empress in the Collection of the Croatian History Museum. It is very similar to the Meytens' portrait of the empress from the Kunsthistorisches Museum in Vienna on display in Schönbrunn, dated from the second half of the $18^{\text {th }}$ century, the slight difference being in the facial features. ${ }^{26}$

A good example of Meytens' workshop is the portrait showing the empress in a pale blue gown, also in the Croatian History Museum. ${ }^{27}$ It is almost the same size as the one given to the Museum by the Bjelovar County. The posture of the empress is identical, numerous details are the same as in the "dark blue" portrait, but the contours of the face as well as details such as hands show distinctive differences, and point to a lesser artist than Martin van Meytens the Younger. ${ }^{28}$ The origin of the portrait is unknown, but we can safely assume it must have been commissioned for an official institution, possibly a county seat.

Another portrait of the empress by Meytens showing her in a pale blue dress is in the holdings of the Varaždin City Museum. ${ }^{29}$ To the right of the empress is the Hungarian crown, behind it the Austrian Archducal hat. Painted probably around 1745, that portrait was bought in Vienna for the Varaždin City Hall around 1750. In 1857 the portrait was retouched by Ferdinand Mayerwieser ${ }^{30}$ and certainly lost some of its splendour, especially in the contours of the face. The most recent restoration work on this large portrait was done by the Croatian Conservation Institute in 2014, restoring to it most of its splendour.

A pair of smaller portraits of the empress and her husband also attributed to Meytens the Younger or his workshop is to be found in the Varaždin City Museum as well. ${ }^{31}$ Francis I is shown in Spanish court dress, with the crown of the Holy Roman Empire to the right, so we can date the portrait as being done after 1745 (he was crowned as the emperor of the Holy Roman Empire in 1745). Maria

26 Hertel, Linsboth, "Maler im Dienste der Kaiserin”, 143.

27 Martin van Meytens the Younger' Workshop, Portrait of Maria Theresia, oil on canvas, 175 x 119 $\mathrm{cm}$, unsigned, Croatian History Museum, inv. no. HPM/PMH 2449. Published for the first time in Schneider, Portreti 16-18. stoljeća, 117.

28 Martin van Meytens the Younger' style of portraiture was taken up by most of the portrait painters between 1740 and 1760 .

29 Martin van Meytens the Younger, portrait of Maria Theresia, oil on canvas, 220 x $160 \mathrm{~cm}$, signature bottom right (hardly legible) "Martin van Meytens", Varaždin City Museum, inv. no. GMV KPO 1440. Published in Dučakijević, "Vladarski portreti Habsburgovaca", 51, catalogued in Bojanić Morandini et al., Varaždin pod krunom Habsburgovaca, 140.

30 Portraitist working in Varaždin, Croatia, in second half of the $19^{\text {th }}$ century.

31 Martin van Meytens the Younger, portrait of Maria Theresia, oil on canvas, 107 x $87 \mathrm{~cm}$, unsigned, Varaždin City Museum, inv. no. GMV KPO 20; Martin van Meytens the Younger, portrait of Francis Stephen, oil on canvas, 90 x $71 \mathrm{~cm}$, unsigned, Varaždin City Museum, inv. no. GMV KPO 19. Catalogued in Bojanić Morandini et al., Varaždin pod krunom Habsburgovaca, 141. 
Theresia is portrayed in a pale blue gown, with a crown to the right (possibly the crown of King Rudolph II [Hauskrone], later on known as the crown of the Austrian Empire).

Picture 5. Johann Geibel, Queen Maria Theresia

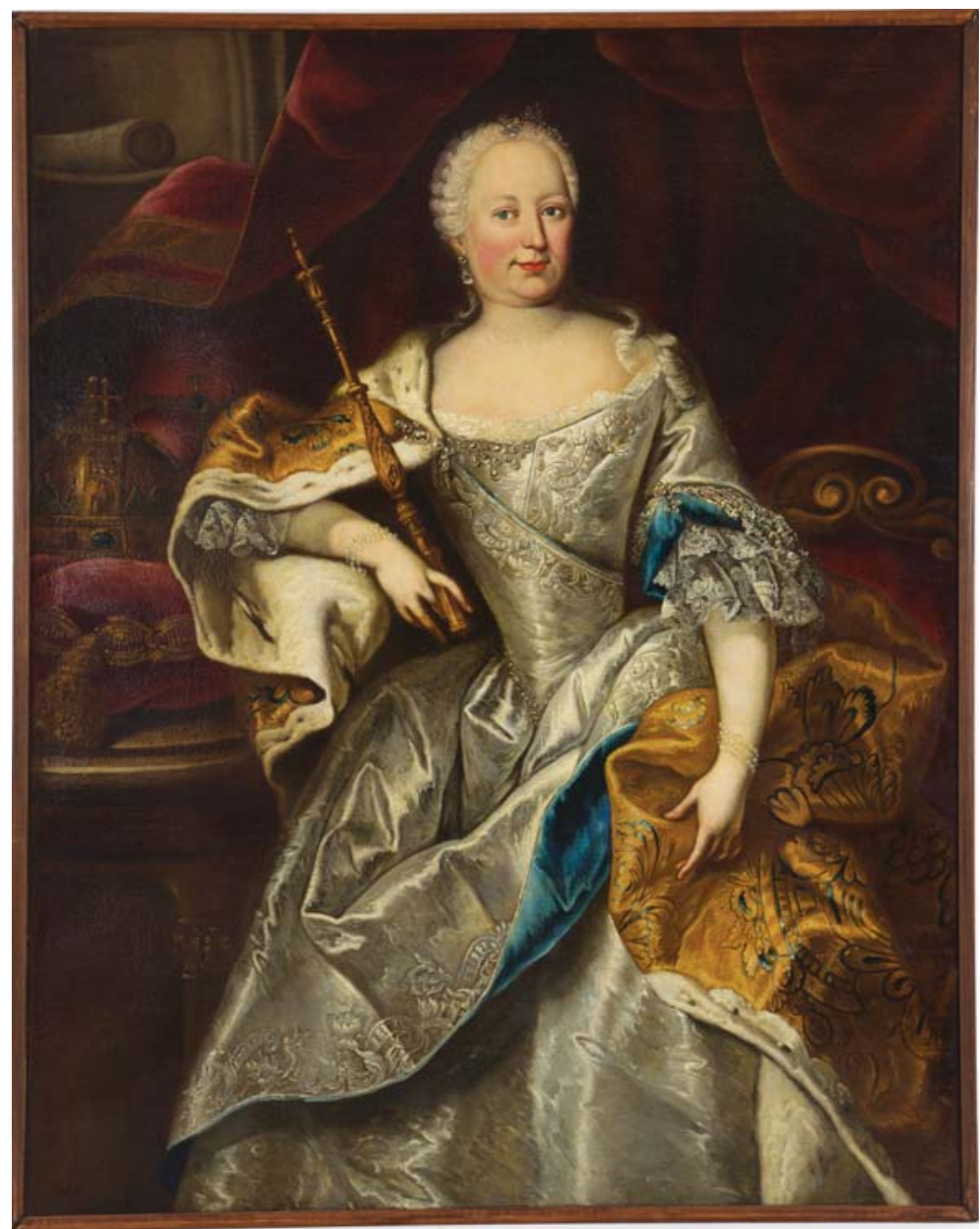

Source: Croatian History Museum, Zagreb (HPM/PMH 2682)

A fairly large portrait of the empress by Johann Geibel was painted in 1750 and given to the Varaždin Border Units, ending up in the $16^{\text {th }}$ Infantry Regiment in Bjelovar, from where it came to the Croatian History Museum in $1919 .{ }^{32}$ On the now lost original frame there was a metal plaque with the inscription: KAISERIN

\footnotetext{
32 Johann Geibel, portrait of Maria Theresia, oil on canvas, 153 x $110 \mathrm{~cm}$, unsigned, Croatian History Museum, inv. no. 2682. Published for the first time in Schneider, Portreti 16-18. stoljeća, 117.
} 
MARIA THEREISA / IHREN TREUEN VARASDINER / GRENZER GEWIDMET 1750 JOHANES GEIBEL. Although nothing is known about the painter, the portrait shows a skilled hand and it is possible that Geibel was a member of Meytens' workshop or from the circle of Johann Gottfried Auerbach ${ }^{33}$ in Vienna. The empress' dress and rich cloak as well as the position her hands in Geibel's painting are fairly similar to the large painting in the Magyar Nemzeti Galéria [Hungarian National Gallery] in Budapest by an unknown Viennese painter from J. G. Auerbach's circle. ${ }^{34}$ The empress is shown quite realistically, thirty-three years old but showing traces of giving birth to eight children. ${ }^{35}$

\section{Portraits by various artists}

The Museum of Arts and Crafts in Zagreb has in its holdings two portraits of the empress. According to the data published on the internet, the first one was probably painted by J. Gamarzer in $1751 .{ }^{36}$ Although the represented lady bears a distant resemblance to the empress, she is shown with no insignia, the only luxurious object on the portrait being a string of pearls she holds with her right hand. The other portrait of the empress in the Museum of Arts and Crafts was painted by an unidentified artist, probably between 1745 and 1755, and donated to the Museum in the first half of the $20^{\text {th }}$ century. ${ }^{37}$

In 1779 the empress donated her portrait together with the portrait of Joseph II to the Gymnasium in Varaždin, both paintings of large dimensions. Maria Theresia went into mourning after the death of her husband in 1765 and was never again seen in anything but widow's weeds. Her portrait by an unknown author (noted in the Museum inventory book as Joseph $\mathrm{Na}$ Chat) was probably painted

\footnotetext{
33 Painter and etcher Johann Gottfried Auerbach (1687 - 1753), one of the outstanding portrait painters of his time, from 1735 court painter, from 1741 onwards Kammermaler to the Viennese court.

34 Magyar Nemzeti Galéria, http://mng.hu/collection/maria-theresa-as-the-queen-of-hungary1264http://mng.hu/collection/maria-theresa-as-the-queen-of-hungary-1264 (last accessed on December 12, 2017). I am grateful to dr Szabolcs Serfözö from Budapest for pointing out that portrait to me.

35 In 1919 the Bjelovar Infantry Regiment handed to the Museum portraits of Maria Theresia and Francis Stephen I by Johannes Geibel. The portrait of Francis Stephen, with the metal plaque dedicating it to the brave Varasdinians ("Tapferen Varasdinern") is not in the Museum's holdings. Schneider, Portreti 16-18. stoljeća, 117.

36 J. Gamarzer, portrait of Maria Theresia, oil on canvas, 86.5 x $71 \mathrm{~cm}$, signature on the obverse: "J. Gamarzer pinxit Aňo 1751". Museum of Arts and Crafts, Zagreb, inv. no. MUO 25803. The portrait can be seen at MUO AthenaPlus, http://athena.muo.hr/?object=detail\&id=29876 (last accessed on November 28, 2017).

37 Unknown painter, portrait of Maria Theresia, oil on canvas, unsigned, 66 x $47 \mathrm{~cm}$, Museum of Arts and Crafts, Zagreb, inv. no. MUO 5363. MUO AthenaPlus, http://athena.muo.hr/?object=detail\&id=23769 (last accessed on November 28, 2017).
} 
after $1770 .^{38}$ The empress is shown in full-length, standing next to a table covered with golden velvet, upon which is a red pillow decorated with golden embroidery and tassels, holding the Hungarian crown and sceptre. Dressed in black, she wears the richly decorated (diamond-studded) Grand Cross of the Order of St. Stephen..$^{39}$ She founded the Royal Hungarian Order of St Stephen in 1764, On the Varaždin portrait Maria Theresia is shown holding a letter in her left hand, near to the crown.

Another, smaller pair of portraits of Maria Theresia and Joseph II by an unknown Viennese painter is also held at the Varaždin City Museum. The empress is shown with the so-called Hauskrone (crown of Rudolph II dating from 1602), holding the sash of the Military Order of Maria Theresia, which she founded in $1757 .^{40}$

In 1856 the Croatian History Museum (the National Museum at that time) received a very valuable donation of portraits from Countess Josipa Kulmer née Oršić - 18 family portraits of members of the Oršić, Kulmer, Drašković and Patačić noble families and a Gallery of portraits of 46 Hungarian and Croatian kings starting with St Stephen and ending with Joseph II. The Gallery of kings was painted in Hungary in the $18^{\text {th }}$ century by at least two, probably three artists. The last three portraits in it show Francis Stephen, Maria Theresia as a widow ${ }^{41}$ and Joseph II. We can only guess if a portrait of the empress matching her husband's appearance was later substituted by a portrait showing her as a widow. Francis Stephen was painted in or after 1757, because apart from the Order of the Golden Fleece he is wearing the sash and the star of the Military Order of

38 Joseph Na Chat (?), portrait of Maria Theresia, oil on canvas, 238 x $157.5 \mathrm{~cm}$, unsigned, Varaždin City Museum, inv. no. GMV GS 504 - KPO 1443. Published in Bojanić Morandini et al., Varaždin pod krunom Habsburgovaca, 144.

39 The Order is easily confused with the Sternkreuzorden [the Noble Order of the Starry Cross], a Catholic noble ladies' decoration founded by the empress Eleonore (1630 - 1686), Emperor Ferdinand III Habsburg's third wife, in 1668 in order to commemorate a lost and found reliquary cross. The empress Eleonore had founded the order "[...] for ladies of nobility, which should be dedicated to the veneration and worship of the Holy Cross and the salvation of the soul." (M. Christian Ortner, Georg Ludwigstorff, Austrian Orders and Decorations, Part I, Volume 2 (Vienna: Heeresgeschichtliches Museum, Militärhistorisches Institut in Vienna, Verlag Militaria, 2016), 380. Empress Maria Theresia was the Most High Patron of the Order (equivalent to Grand Mistress). The order was bestowed upon noble ladies who were able to prove eight generations of nobility in both their fathers' and mothers' lineages. It was very highly thought of; there are a number of noble ladies' portraits in the Collection of Paintings of the Croatian History Museum from $18^{\text {th }}$ to the end of $19^{\text {th }}$ centuries showing them wearing the Sternkreuzorden.

40 Unknown painter, portrait of Maria Theresia, oil on canvas, 86 x $72 \mathrm{~cm}$, Varaždin City Museum, inv. no. GMV KPO 728. As the portrait is not published, my thanks for the data to Mrs. Ljerka Šimunić, Museum Advisor, Curator of the Cultural and Historical Department of the Varaždin City Museum.

${ }^{41}$ Unknown painter, portrait of Maria Theresia, oil on canvas, $40 \times 30 \mathrm{~cm}$, unsigned, Croatian History Museum, inv. no. HPM/PMH 8682. Published in Schneider, Portreti 16-18. stoljeća, 55-56, also in Mladen Ančić et al., Kolomanov put, exhibition catalogue, (Zagreb: Croatian History Museum, 2002), 217-218. 
Maria Theresia (founded in 1757). ${ }^{42}$ Joseph II is also wearing the Military Order of Maria Theresia and the Royal Hungarian Order of St Stephen (founded by the empress in 1764), which would date his portrait in or after $1764 .{ }^{43}$

The Collection of Paintings of the Croatian History Museum also holds a portrait of the monarch that can be categorised as a historical portrait as it was painted in the second half of the $19^{\text {th }}$ century by the Viennese painter Friedrich Krepp (Vienna, 1830 - after 1862), who worked in Vienna from 1852 to 1862. The empress is shown in a black satin gown, her left hand over the Austrian Archducal Hat, and with the Military Order of Maria Theresia below it. ${ }^{44}$ She wears the Sternkreuzorden. Krepp had used the classic baroque arrangement of the hand over the crown, but the other elements in the painting, especially the green leaves to the left, point towards $19^{\text {th }}$ century portraiture.

\section{Conclusion}

Museum collections in Zagreb, Varaždin and Trakošćan hold a significant number of portraits of Maria Theresia, the smaller ones usually showing her as Austrian archduchess and heiress to the throne, intended for noble homes of Croatia. The portraits of Maria Theresia as empress painted between 1740 and 1770 tend to be of larger format, intended for town halls, military units or other official places, from which they were donated to the museums in Varaždin and Zagreb. Many of those are attributed to Martin van Meytens the Younger, a favourite court painter of Maria Theresia and her family. Together with his workshop Meytens had provided the whole Austrian Empire with numerous portraits of the monarch, usually adorned with the crowns symbolising her power over the countries she ruled.

Portraits of Empress Maria Theresia in museum collections of north-western Croatia depict the monarch in different stages of her life - as a young archduchess and heiress to the throne, a mighty ruler and mother, and finally a grieving widow - painted by court painters, anonymous skilled and less skilled artists. They remain a constant reminder of the greatness she had achieved as the only female monarch of the vast multinational Habsburg Empire.

\footnotetext{
42 Unknown painter, portrait of Francis Stephen, oil on canvas, 40 × $30 \mathrm{~cm}$, unsigned, Croatian History Museum, inv. no. HPM/PMH 8684. Published in Schneider, Portreti 16-18. stoljeća, 56, also in Ančić et al., Kolomanov put, 218.

${ }^{43}$ Unknown painter, portrait of Joseph II, oil on canvas, 40 x $30 \mathrm{~cm}$, unsigned, Croatian History Museum, inv. no. HPM/PMH 8683. Published in Schneider, Portreti 16-18. stoljeća, 56-57, also in Ančić et al., Kolomanov put, 218.

${ }_{44}$ Friedrich Krepp, portrait of Maria Theresia, oil on canvas, $156 \times 101 \mathrm{~cm}$, signature bottom right "Krepp", Croatian History Museum, inv. no. HPM/PMH 2450. Origin unknown. Published in Schneider, Portreti 16-18. stoljeća, 118.
} 


\section{Published sources and literature}

Ančić, Mladen et al. Kolomanov put. Exhibition catalogue. Zagreb: Croatian History Museum, 2002

Bojanić Morandini, Miran et al. Varaždin pod krunom Habsburgovaca. Exhibition catalogue. Varaždin: Gradski muzej Varaždin, 2015

Bregovac Pisk, Marina. “Obitelj Drašković kao naručitelji i kupci umjetnina (na primjeru Dvora Trakošćan)”. Doctoral thesis, University of Zagreb, Faculty of Humanities and Social Sciences, 2012.

Dučakijević, Mirjana. "Vladarski portreti Habsburgovaca u Gradskom muzeju Varaždin”. In: Varaždin pod krunom Habsburgovaca. Exhibition catalogue. Varaždin: Gradski muzej Varaždin, 2015.

Hanzelová, Zuzana. Retrospect to Bratislava Coronations (From the collection of the Bratislava Gallery). Bratislava: Galérie mesta Bratislavy, 1992.

Hertel, Sandra; Linsboth, Stefanie. "Maler im Dienste der Kaiserin - Maria Theresia als Reformerin und Mäzenin der Kunstproduktion". In: Maria Theresia 1717 - 1780, Strategin - Mutter - Reformerin. Iby, Elfriede; Mutschlechner, Martin; Telesko, Werner; Vocelka, Karl, ed. Vienna: Schloss Schönbrunn, Amalthea and Kunsthistorisches Museum, 2017.

Lechner, Georg. Martin van Meytens der Jüngere. Exhibition catalogue, ed. Agnes Husslein-Arco and Georg Lechner. Vienna: Belvedere, 2014.

Mraz, Gerda; Schlag, Gerald, eds. Maria Theresia als Königin von Ungarn: Schloß Halbturn. Exhibition catalogue. Eisenstadt: Amt der Burgenländischen Landesregierung, 1980.

Ortner, M. Christian; Ludwigstorff, Georg. Austrian Orders and Decorations, Part I, Volume 2. Vienna: Heeresgeschichtliches Museum, Militärhistorisches Institut in Vienna, Verlag Militaria, 2016.

Pfundner, Michaela; Mauthe, Gabriele, eds. Maria Theresia. Habsburgs mächtigste Frau. Vienna: Metroverlag, 2017.

Rollig, Stella; Lechner, Georg, eds. Maria Theresa and the Arts. Vienna: Belvedere; Munich: Hirmer Verlag GmbH, 2017.

Schneider, Marijana. Portreti 16-18. stoljeća. Zagreb: Povijesni muzej Hrvatske, 1982.

Serfőző, Szabolc. “,Männlich` und mächtig, Die Inszenierung Maria Theresias als Königin von Ungarn auf Staatsporträts”. In: Maria Theresia 1717 - 1780, Strategin - Mutter - Reformerin. Iby, Elfriede; Mutschlechner, Martin; Telesko, Werner; Vocelka, Karl, eds. Vienna: Schloss Schönbrunn, Amalthea and Kunsthistorisches Museum, 2017. 


\section{Internet sources}

Krafft, Jan Lauwryn, Möller, Andreas, \& Zpor_Por. (1742). Maria Theresia, Römisch-deutsche Kaiserin. Austrian National Library (Österreichische Nationalbibliothek), Vienna, http://data.onb.ac.at/rec/baa4831344, (last accessed on November 28, 2017).

Magyar Nemzeti Galéria, Budapest, http://mng.hu/collection/maria-theresaas-the-queen-of-hungary-1264http://mng.hu/collection/maria-theresa-as-thequeen-of-hungary-1264 (last accessed on December 12, 2017).

Mária Terézia na koni. Martin Engelbrecht, Christian Wilhelm. Web umenia, Bratislava, https://www.webumenia.sk/dielo/SVK:GMB.C_7635 (last accessed on November 28, 2017).

MUO-025803: Portret Marije Terezije: slika. MUO AthenaPlus, Zagreb, http:// athena.muo.hr/?object=detail\&id=29876 (last accessed on November 28, 2017).

MUO-005363: Marija Terezija: slika. MUO AthenaPlus, Zagreb, http://athena. muo.hr/?object=detail\&id=23769 (last accessed on November 28, 2017).

Schmittner, Leopold, Stampart, Frans van, \& Zpor_Por. (1740). Maria Theresia, Römisch-deutsche Kaiserin. Austrian National Library (Österreichische Nationalbibliothek), Vienna, http://data.onb.ac.at/rec/baa4831566 (last accessed on December 1, 2017). 
Marina Bregovac Pisk ${ }^{*}$

\section{Portreti kraljice i carice Marije Terezije u sjeverozapadnoj Hrvatskoj Pregled}

\section{Sažetak}

Članak donosi kronološki pregled portreta carice i kraljice Marije Terezije koji se čuvaju u muzejskim zbirkama sjeverozapadne Hrvatske, poglavito u Zagrebu, Varaždinu i Trakošćanu. Rani portreti Marije Terezije kao prijestolonasljednice veličinom su manji i prikazuju je kao austrijsku nadvojvotkinju, dok su portreti slikani nakon njezina stupanja na prijestolje uglavnom veliki čime naglašavaju svoju službenu namjenu. Različite su kvalitete, od onih koji su djela poznatih bečkih dvorskih slikara do prikaza neutvrđenih vještih ili manje vještih umjetnika. Martin van Meytens Mlađi ističe se kao najistaknutiji portretist vladarice; zajedno sa svojom radionicom slikao je portrete Marije Terezije i njezina supruga za čitavo područje austrijskog carstva. Većina portreta slikanih između 1741. i 1760. koji se nalaze u muzejskim zbirkama sjeverozapadne Hrvatske pripisuje se Meytensu i / ili njegovoj radionici.

Portreti Marije Terezije u muzejskim zbirkama sjeverozapadne Hrvatske predstavljaju nam vladaricu u različitim razdobljima njezina života - kao mladu nadvojvotkinju i prijestolonasljednicu, moćnu vladaricu i majku, te konačno kao žalujuću udovicu. Oni ostaju stalan podsjetnik na veličinu koju je postigla kao jedina žena vladarica velikih multinacionalnih habsburških zemalja.

Ključne riječi: Marija Terezija, portreti, muzejske zbirke, sjeverozapadna Hrvatska, Martin van Meytens

Marina Bregovac Pisk, Hrvatski povijesni muzej, Matoševa 9, 10000 Zagreb, Republika Hrvatska, E-mail adresa: m.pisk@hismus.hr 